\title{
Evaluation of CNS stimulating activity of hydroalcoholic extract of Brassica oleracea L.var. italica in laboratory animals
}

\author{
G. V. Sutar, S. J. Sajane, S. T. Taralekar, Prakash I. Nargatti` and A. A. Jadhav** \\ Department of Pharmacology, Annasaheb Dange College of Pharmacy, Ashta, Walwa, Sangli-416301, Maharashtra, India \\ *Department of Pharmacology, YSPMs, Yashoda Technical Campus, Faculty of Pharmacy, Satara, Satara-415011, Maharashtra, India
}

\section{Article Info}

Article history

Received 2 October 2021

Revised 19 November 2021

Accepted 20 November 2021

Published Online 30 December 2021

Keywords
BOVLI
CNS stimulant
Actophotometer
Y maze
Dopamine
Serotonin

\section{Introduction}

Depression is a chronic mental disorder that causes changes in mood, thoughts, behavior and physical health. It is a common but serious disease that can take away a person's ability to enjoy life and cause decline in capacity to undertake even the simplest daily tasks (Fekadu et al., 2017). As per WHO (2017) estimation, around clinical depression affects 121 million people globally. Suicide will be the second largest cause of death by 2020 , owing to the high prevalence of suicide in depressed patients (up to $15 \%$ ), as well as complications originating from stress and its impact on the cardiovascular system (Agarwal et al., 2015). Patients who are having major depression may have effect on level of dopamine, norepinephrine and serotonin (Jayanthi et al., 2012; Patil et al., 2021; Nargatti et al., 2021). Therefore, CNS stimulants are essential drugs whose primary action is to stimulate the CNS activity or to improve the specific physical and mental brain functions (Sonpetkar et al., 2012; Tripathi, 2013). CNS stimulants are useful for reducing drowsiness and fatigue and increasing mental alertness (Saha and Banerjee, 2013). From the past, few decades herbal medicines have been used not only for treatment but also for cure of diseases and its disorders (Bishwo et al., 2016). Ethnomedicinally, herbs are used in the treatment of pain relief, wound healing and abolishing fever that bring useful information to identify a wide range of compounds to develop new therapies for cancer, hypertension, diabetes and antiinfective medicines (Zaman et al., 2015). There

\section{Corresponding author: Mr. Prakash I. Nargatti}

Department of Pharmacology, Annasaheb Dange College of Pharmacy, Ashta, Walwa, Sangli-416301, Maharashtra, India.

E-mail: prakashnargatti@gmail.com

Tel.: +91-7709884468

Copyright (c) 2021 Ukaaz Publications. All rights reserved.

Email: ukaaz@yahoo.com; Website: www.ukaazpublications.com are numerous synthetic antidepressant and CNS stimulant medicines available in the market today; however, their efficacy does not extend to the full population suffering from this illness. Further more, side effects and drug interactions are significant limitations in their clinical use. Therefore, herbal medicines are utilized all over the world to prevent the negative effects of synthetic pharmaceuticals because of its wide application and therapeutic efficacy with little side effects. Mahuang (Ephedra vulgaris Rich.) in China, Khat (Catha edulis Forsk) in Africa, and Coca (Erythroxylum coca Lam.) in South America are examples of the drugs which have been used as CNS stimulant from ancient times (Mestry et al., 2016).

Of late, Brassica oleracea L.var. italica Plenck (BOVLI) provides many health-promoting properties with its high antioxidant nature. Not only that, it also claims essential therapeutic benefits with its bioactive compounds. Phytochemical analysis of Broccoli has been showed presence of phenolic compounds, particularly flavonoids, vitamin $\mathrm{C}$ and $\mathrm{E}$, amino acids, flavonols like quercetin and kaempferol, the carotenoids b-carotene, lutein, and the glucosinolates (Leja et al., 2001). Various parts of the plant have been scientifically proved for many activities, viz., antianemic activity (Vamsee et al., 2015), antibacterial activity (Sibi et al., 2013), anticancer activity (Talreja and Moon, 2014), antidementic activity (Ashwlayan, 2017), antidiabetic activity (Shah et al., 2016), antigenotoxic effects (Kumari et al., 2012), and antioxidant (Bhagat et al., 2012), but scanty information or no such scientific evidences were established on CNS stimulant activity on BOVLI florets hydroalcoholic extract. Therefore, it was worthwhile to investigate BOVLI florets or Broccoli heads for CNS stimulant activity in laboratory animals. 


\section{Materials and Methods}

\subsection{Plant material and extraction}

The plant was collected from Satara region of Maharashtra in the month of October-November 2017 and was authenticated by Department of Botany, Yashwantrao Chavan Institute of Science, Satara. The voucher specimen of BOVLI was stored as herbarium in Pharmacognosy Department (Herbarium No: BOVLI-104/PCOG2019-20), Annasaheb Dange College of Pharmacy, Sangli, Maharashtra. The florets parts of BOVLI were dried under shade and coarsely powdered by using grinder mixer. $500 \mathrm{~g}$ of dried material was used for the extract preparation. The hydroalcoholic extract (2:1) was prepared by Soxhlet extraction for $9 \mathrm{~h}$ at $40^{\circ} \mathrm{C}$ temp. Further, the extract was dried using rotary flash evaporator at $45^{\circ}$ $\mathrm{C}$ to get viscous semisolid crude extract. The final semisolid mass of crude extract was stored in $4^{\circ} \mathrm{C}$ in refrigerator using $100 \mathrm{ml}$ glass bottles for retaining the potency of the bioactive compounds for the said experimentation.

\subsection{Yield and phytochemical screening}

The yield of the crude extract followed by phytochemical screening of the stored florets parts of BOVLI hydroalcoholic extract was performed for presence of group of phytochemicals.

\subsection{Animals}

Albino Wistar rats (150-200 gm) of either sex were used. The temperature in the experimental animal room was $22^{\circ} \mathrm{C}\left( \pm 3^{\circ} \mathrm{C}\right)$. Artificial lighting the sequence being $12 \mathrm{~h}$ light, $12 \mathrm{~h}$ dark was maintained. For feeding, conventional laboratory diets was used with an unlimited supply of drinking water. Total 66 animals were used for the study. All the experimental protocols were approved by Institutional Animal Ethics Committee (IAEC) (Protocol No. YSPM/YTC/PHARM/18/2017) and were conducted according to the principles and guidelines of the committee for the purpose of control and supervision of experimentation on animals, India.

\subsection{Chemicals and drugs}

For the conduction of the said experimentation, phenobarbitone (Phenobarbitone injection, Nitin Lifesciences Ltd.) and caffeine (Cafneon injection, Neon Laboratories Ltd. Mumbai) were procured.

\subsection{Acute oral toxicity}

The acute oral toxicity (AOT) study of hydroalcoholic extract of BOVLI was carried out as per OECD guidelines No. 423. Female Albino rats $(n=6)$ were used for toxicity study. The oral dose (2000 and $4000 \mathrm{mg} / \mathrm{kg}$ ) of tested plant extract was administered to two groups in single dose and general behavior, adverse effects and mortality were determined up to $72 \mathrm{~h}$ and compared to normal group (Kifayatullah et al., 2015).

\subsection{Experimental models}

Locomotor activity using actophotometer apparatus and Y maze test were followed for the study as in vivo models and thereby, dopamine and serotonin were estimated from brain tissues of experimental rats.

\subsubsection{Locomotor activity}

The locomotor activity can be an index of wakefulness (alertness) of mental activity. Actophotometer is used for measuring locomotor activity which photoelectric cells are connected in circuit with a counter. When the beam of light falling on the photocell was cut off by the animal, a count was recorded. Animals were divided in five groups each comprising six animals. The dose was selected as per acute toxicity studies based on safety dose.

- Control group was treated with normal saline solution.

- Negative control group was treated with phenobarbitone (50 $\mathrm{mg} / \mathrm{kg}$ ) dose.

- Standard was treated with phenobarbitone $(50 \mathrm{mg} / \mathrm{kg})$ dose and caffeine $(10 \mathrm{mg} / \mathrm{kg})$ dose.

- Test I group was treated with phenobarbitone $(50 \mathrm{mg} / \mathrm{kg})$ dose and hydroalcoholic extract of BOVLI $(200 \mathrm{mg} / \mathrm{kg})$ low dose.

- Test II group was treated with phenobarbitone $(50 \mathrm{mg} / \mathrm{kg})$ dose and hydroalcoholic extract of BOVLI $(400 \mathrm{mg} / \mathrm{kg})$ high dose.

Each rat was separately placed in an actophotometer for duration of $10 \mathrm{~min} 1 \mathrm{~h}$ after the treatments. The count was recorded on the display when the beam of light landing on the photocells was cut by the moving animal (Kulkarni, 2011; Bora et al., 2015).

\subsubsection{Y maze test}

Y maze test has been shown to be reliable and effective in rodents for evaluation of the spontaneous alternation behavior (Sibi et al., 2013). Y maze composed of three equally spaced arms $\left(120^{\circ}, 50\right.$ $\mathrm{cm}$ long and $18 \mathrm{~cm}$ height, $15 \mathrm{~cm}$ width). Animals were divided in five groups each comprising six animals. It was performed for all groups of the rats at 30,60,90 and 120 min by placed individually in a symmetrical Y-shaped runway for $3 \mathrm{~min}$ and the number of the maze with all $4 \mathrm{ft}$ (an 'entry') were counted.

- Control group was treated with normal saline solution.

- Negative control group was treated with phenobarbitone (50 $\mathrm{mg} / \mathrm{kg}$ ) dose.

- Standard was treated with phenobarbitone $(50 \mathrm{mg} / \mathrm{kg})$ dose and caffeine $(10 \mathrm{mg} / \mathrm{kg})$ dose.

- Test I group was treated with phenobarbitone $(50 \mathrm{mg} / \mathrm{kg})$ dose and hydroalcoholic extract of BOVLI $(200 \mathrm{mg} / \mathrm{kg})$ dose.

- Test II group was treated with phenobarbitone $(50 \mathrm{mg} / \mathrm{kg})$ dose and hydroalcoholic extract of BOVLI $(400 \mathrm{mg} / \mathrm{kg})$ dose.

Each rat was placed in one of the arm compartments and was allowed to move for $10 \mathrm{~min}$ freely until its tail completely enters another arm. The sequence of arm entries was manually recorded, the arms being labeled A, B, or C. The number of times a rat entered in the arm of the maze with all four feet was counted as a single entry and used for the comparison of control and drug treated groups (Avijit et al., 2010).

\section{In vitro models}

\subsection{Estimation of dopamine and serotonin from rat brain tissue}

\subsubsection{Preparation of tissue extracts}

The rats were sacrificed after completion of Y maze experiment; the entire brain was taken out and the forebrain was separated. The tissue was weighed and homogenized in $0.1 \mathrm{ml}$ hydrochloric acid and $\mathrm{n}$-butanol $(0.85 \mathrm{ml}$ of 37 per cent hydrochloric acid in one-liter $\mathrm{n}$ - butanol by spectroscopy for $1 \mathrm{~min}$ in a cool environment). After 
that, the sample was centrifuged for $10 \mathrm{~min}$ at $2,000 \mathrm{rpm}$. Separate $0.08 \mathrm{ml}$ of supernatant to an eppendorf tube containing $0.2 \mathrm{ml}$ heptane (for spectroscopy) and $0.025 \mathrm{ml} 0.1 \mathrm{M}$ hydrochloric acid. The tube was centrifuged under the same settings after $10 \mathrm{~min}$ of vigorous shaking to separate the two phases. Upper organic phase was discarded and lower the aqueous phase $(0.02 \mathrm{ml})$ was used for estimation of serotonin, and dopamine assay.

\subsubsection{Estimation of dopamine}

The assay represents a miniaturization of the trihydroxide method. To $0.02 \mathrm{ml}$ of $\mathrm{HCl}$ phase, $0.05 \mathrm{ml} 0.4 \mathrm{M}$ and $0.01 \mathrm{ml}$ EDTA/sodium acetate buffer were added in $0.02 \mathrm{ml}$ of $\mathrm{HCl}$ and $\mathrm{pH}$ maintained at 9 . Then, $0.01 \mathrm{ml}$ of iodine solution (prepared with $0.1 \mathrm{M}$ ethanol) added and kept for $10 \mathrm{~min}$ for oxidation. The reaction was stored after 2 min by addition of $0.01 \mathrm{ml} \mathrm{Na}_{2} \mathrm{SO}_{3}$ in $5 \mathrm{M} \mathrm{NaOH}$. Acetic acid was added $1.5 \mathrm{~min}$ later. The solution was then heated to $100^{\circ} \mathrm{C}$ for $6 \mathrm{~min}$. When the sample again reached room temperature, excitation and emission spectra were read in the microcuvette as with 5-HT by the photofluorometer at 330-375 nm (Das et al., 2008) and the dopamine level was estimated.

\subsubsection{Estimation of serotonin}

To estimate serotonin level, reduced volume for 5- HT determination, the O-pthaldialdehyde (OPT) method was followed. From the OPT reagent, $0.025 \mathrm{ml}$ were added to $0.02 \mathrm{ml}$ of the $\mathrm{HCl}$ extract. The mixture was heated at $100^{\circ} \mathrm{C}$ for $10 \mathrm{~min}$ to form fluorophore. After the samples reached equilibrium with the ambient temperature, excitation/estimation spectra or intensity reading at 360-470 nm by using the photofluorometer (Das et al., 2008).

\subsubsection{Statistical analysis}

The results were expressed as mean \pm SEM. Statistical analysis of difference between groups was evaluated by ANOVA, followed by Tukey's multiple comparison test. $p$ values less than 0.05 were considered significant.

\section{Results}

\subsection{Yield and preliminary phytochemical screening}

The yield of the extract was calculated and reveled the amount of the crude extract was $189.56 \mathrm{~g}(\mathrm{w} / \mathrm{w})$ or $37.91 \%$. Further, preliminary phytochemical screening for the same extract was carried out and revealed the presence of some active principles which was tabulated in Table 1.

\subsection{Acute toxicity}

The acute toxic effect of hydroalcoholic BOVLI extract was determined as per the OECD guideline, 423 at higher dose of 4000 $\mathrm{mg} / \mathrm{kg}$ was used. No treatment related toxic symptom or mortality was observed after oral administration of the hydroalcoholic BOVLI extract at a dose of 2000 and $4000 \mathrm{mg} / \mathrm{kg}$. The general behavioral of the extract treated animals and control group was observed for initially $4 \mathrm{~h}$ followed by long period $72 \mathrm{~h}$. It was revealed that no abnormalities in behavior, breathing, skin effects, water consumption, impairment in food intake and temperature or any death occurred for the all 6 animals. Therefore, the extract may be safe at a dose level of $4000 \mathrm{mg} / \mathrm{kg}$, and the $\mathrm{LD}_{50}$ dose for the extract was considered be more than $4000 \mathrm{mg} / \mathrm{kg}$.
Table 1: Preliminary phytochemical screening of hydroalcoholic extracts of BOVLI

\begin{tabular}{|c|l|c|}
\hline Sr. No. & Plant constituents & Hydroalcoholic extract \\
\hline 1 & Alkaloids & + \\
2 & Flavonoids & + \\
3 & Tannins & + \\
4 & Carbohydrates & + \\
5 & Glycosides & + \\
5 & Saponins & + \\
6 & Terpenoids & + \\
7 & Phenols & - \\
8 & Resins & - \\
9 & Protein & + \\
10. & Sterols & + \\
\hline
\end{tabular}

$(+)=$ present; $(-)=$ Absent

4.3 Evaluation of locomotor activity using actophotometer apparatus

The locomotor activity of the animals was determined and compared with the normal control, negative control and with the standard. The result revealed that hydroalcoholic BOVLI extract in low dose $(304.5 \mathrm{sec})$ and high dose $(321.8 \mathrm{sec})$, both showed significantly higher activity than phenobarbitone alone, but the result was lesser than standard drugs $(576.2 \mathrm{sec})$. The dose of $400 \mathrm{mg} / \mathrm{kg}$ has shown significant increase in locomotor activity $(p<0.001)$ (Figure 1$)$.

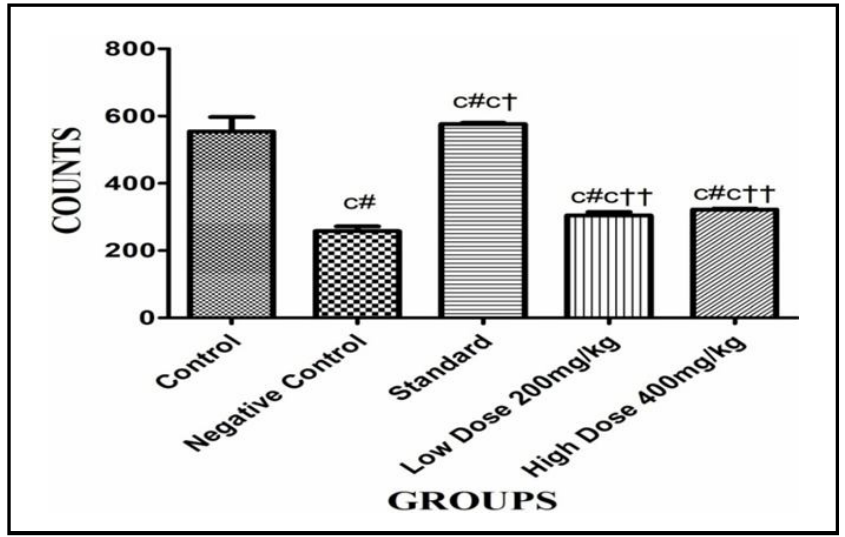

Figure 1: Effect of hydroalcoholic extracts of BOVLI on locomotor activity.

Values represent mean $\pm S E M ; n=6$; analysis was performed using one-way ANOVA, followed by Tukey's multiple comparison test. $p<0.05$ was considered as statistically significant. ${ }^{\mathrm{a}} p<0.05,{ }^{\mathrm{b}} p<0.01$, ${ }^{\mathrm{c}} p<0.001$. "Data compared with normal control. *Data compared with negative control. **Data compared with standard treatment.

\subsection{Evaluation of $Y$ maze apparatus test}

The neuropharmacological study was evaluated through Y maze apparatus. The extract showed significant increase in exploratory behavior in $\mathrm{Y}$ maze test as compared to negative control, showed its CNS stimulating activity (Table 2). 
Table 2: Effect of hydroalcoholic extracts of BOVLI on Y maze

\begin{tabular}{|c|c|c|c|c|}
\hline \multirow[t]{2}{*}{ Treatment } & \multicolumn{4}{|c|}{ Total number of counts (min) } \\
\hline & 30 & 60 & 90 & 120 \\
\hline Control & $12.66 \pm 0.917$ & $12.64 \pm 0.915$ & $12.63 \pm 0.910$ & $12.68 \pm 0.918$ \\
\hline Negative control $(50 \mathrm{mg} / \mathrm{kg})$ & $7.656 \pm 0.421 \mathrm{c} \#$ & $7.665 \pm 0.432 \mathrm{c} \#$ & $7.657 \pm 0.421 \mathrm{c} \#$ & $7.667 \pm 0.426 \mathrm{c} \#$ \\
\hline Standard $(10 \mathrm{mg} / \mathrm{kg})$ & $21.63 \pm 1.26 \mathrm{c \# c} \dagger$ & $21.66 \pm 1.25 \mathrm{c \# c} \dagger$ & $21.62 \pm 1.22 \mathrm{c \# c} \dagger$ & $21.67 \pm 1.24 \mathrm{c \# c} \dagger$ \\
\hline Low dose $(200 \mathrm{mg} / \mathrm{kg})$ & $12.12 \pm 0.741 \mathrm{c \# c \dagger \dagger}$ & $12.14 \pm 0.742 \# c+\dagger$ & $12.15 \pm 0.731 \mathrm{c \# c \dagger \dagger}$ & $12.17 \pm 0.721 \mathrm{c \# c} \dagger \dagger$ \\
\hline High dose $(400 \mathrm{mg} / \mathrm{kg})$ & $15.83 \pm 0.741 \mathrm{c \# c} \dagger \dagger$ & $15.84 \pm 0.743 \mathrm{c} \# \mathrm{c} \dagger \dagger$ & $15.82 \pm 0.744 \mathrm{c \# c} \dagger \dagger$ & $15.86 \pm 0.749 \mathrm{c} \# \mathrm{c} \dagger \dagger$ \\
\hline
\end{tabular}

Values represent mean \pm SEM; $n=6$; analysis was performed using one-way ANOVA, followed by Tukey's multiple comparison test. $p<0.05$ was considered as statistically significant. ${ }^{\mathrm{a}} p<0.05,{ }^{\mathrm{b}} p<0.01$, ${ }^{c} p<0.001$. "Data compared with normal control. Data compared with negative control. ${ }^{\dagger}$ Data compared with standard treatment.

\subsection{Estimation of dopamine level from brain tissue}

Dopamine level for each group of animals was calculated from the homogenized brain tissue and result revealed increased level of dopamine concentration as increased in dose of the hydroalcoholic extracts of BOVLI. It has also shown that extract of $400 \mathrm{mg} / \mathrm{kg}$ dose was more significantly higher $(457.3 \mathrm{pg} / \mathrm{mg})$ than negative control and lesser than standard drug, caffeine (Table 3).

Table 3: Effect of hydroalcoholic extracts of BOVLI on dopamine level from rat brain tissue

\begin{tabular}{|l|c|}
\hline Treatment & Dopamine level $(\mathbf{p g} / \mathbf{~ m g})$ \\
\hline Control & $407.3 \pm 4.402$ \\
Negative control $(50 \mathrm{mg} / \mathrm{kg})$ & $89.17 \pm 1.701 \mathrm{c \#}$ \\
Standard $(10 \mathrm{mg} / \mathrm{kg})$ & $518.5 \pm 4.752 \mathrm{c} \# \mathrm{c} \dagger$ \\
Low dose $(200 \mathrm{mg} / \mathrm{kg})$ & $421.3 \pm 2.906 \mathrm{c} \dagger \mathrm{c} \dagger \dagger$ \\
High dose $(400 \mathrm{mg} / \mathrm{kg})$ & $457.3 \pm 3.818 \mathrm{c \# c} \dagger \mathrm{c} \dagger \dagger$ \\
\hline
\end{tabular}

Values represent mean \pm SEM; $n=6$; analysis was performed using one-way ANOVA, followed by Tukey's multiple comparison test. $p<0.05$ was considered as statistically significant. ${ }^{\mathrm{a}} p<0.05,{ }^{\mathrm{b}} p<0.01$, ${ }^{c} p<0.001$. "Data compared with normal control. 'Data compared with negative control. ${ }^{\dagger}$ Data compared with standard treatment.

\subsection{Estimation of serotonin level from rat brain tissue}

The serotonin level similarly evaluated for each group of animals from the homogenized brain tissue and result revealed increased level of serotonin concentration as increased in dose of the hydroalcoholic extracts of BOVLI. The result was depicted in Table 4 .

Table 4: Effect of hydroalcoholic extracts of BOVLI on serotonin level from rat brain tissue

\begin{tabular}{|c|c|}
\hline Treatment & Serotonin level (pg/ mg) \\
\hline Control & $87.33 \pm 2.848$ \\
\hline Negative control $(50 \mathrm{mg} / \mathrm{kg})$ & $97.00 \pm 2.978$ \\
\hline Standard $(10 \mathrm{mg} / \mathrm{kg})$ & $198.3 \pm 5.364 \mathrm{c} \# \mathrm{c} \dagger$ \\
\hline Low dose $(200 \mathrm{mg} / \mathrm{kg})$ & $132.8 \pm 2.272 \mathrm{c \# c} \dagger \mathrm{c} \dagger \dagger$ \\
\hline High dose $(400 \mathrm{mg} / \mathrm{kg})$ & $142.3 \pm 1.626 \mathrm{c \# c} \dagger \mathrm{c} \dagger \dagger$ \\
\hline
\end{tabular}

Values represent mean $\pm S E M ; n=6$; analysis was performed using one-way ANOVA, followed by Tukey's multiple comparison test. $\mathrm{p}$ value less than 0.05 was considered as statistically significant. ${ }^{\mathrm{a}} p<0.05,{ }^{\mathrm{b}} p<0.01,{ }^{\mathrm{c}} p<0.001$. "Data compared with normal control. 'Data compared with negative control. ${ }^{\dagger}$ Data compared with standard treatment.

\section{Discussion}

Depression is a common mental disorder and one of the most important causes of disability in the world, especially during COVID19 pandemic. The rate of the same drastically increased due to lock down effect. A vast number of medicinal plants are effectively used for the treatment of the same from the ancient period. Many are scientifically proved, and some are still in process to establish their efficacy. After the isolation of active constituents, such as morphine from opium poppies, scientific understanding of psychoactive plants has significantly advanced over the last two centuries (Sarris et al., 2011). Established classes of CNS stimulants have shown side effects like euphoria dizziness, tremor, convulsions circulatory collapse, etc.

To overcome the side effects of synthetic drugs hydroalcoholic extract of B. oleracea was investigated for CNS stimulant activity. Preliminary the phytochemical screening of the hydroalcoholic extract of BOVLI florets showed the presence of many essential phytochemicals which are significantly contributes in many therapeutic efficacies. The yield of the extract was more in hydroalcoholic extract because many of the phytoconstituents are soluble in the same and resulted higher yield and also the presence of many bioactive compounds. The same result was also revealed by the earlier scientific data (Kaneria et al., 2012).

In the present study, caffeine is used as standard drug for the CNS stimulating activity because caffeine is competitive antagonist at adenosine receptor and produces range of central and physiological effects that are opposing those of adenosine. Caffeine mobilizes intracellular calcium in neurons by reducing calcium uptake in microsomal vesicles and stimulates calcium release from the endoplasmic reticulum. Increase in intracellular calcium concentrations causes the release of neurotransmitters such as norepinephrine (NE) and dopamine (Alasmari, 2020). In negative control, phenobarbitone was used as CNS depressant agent that acts on GABA Benzodiazepine (BZD) receptor-Cl channel complex and potentiates GABA ergic inhibition by prolongation of opening of $-\mathrm{Cl}$ channel (Tripathi, 2013). BOVLI is a rich source of flavonoids. Flavonoids acts on different systems of brain. Flavanols, flavanones and anthocyanins may act in protective ways, increasing the cerebral 
blood flow and protecting the neurons against inflammatory processes leading to cell injury (Jäger and Saaby, 2011).

Acute oral toxicity study was performed at the dose of $4000 \mathrm{mg} / \mathrm{kg}$ and showed the extract was safe, and hence any two doses, i.e., 200 $\mathrm{mg} / \mathrm{kg}$ and $400 \mathrm{mg} / \mathrm{kg}$ were selected as low dose and high dose, respectively. The assessment of CNS activity of any drug depends on the locomotor activity of animals which was carried out by using actophotometer. The locomotor activity of animal was determined by the estimation of excitability of the CNS level. An increase in alertness referred to as locomotor activity whereas the same indicates sedative effect when it decreases. There is a close relationship between increased locomotor activity and stimulation which is derived from CNS stimulation (Aziz and Sarkar, 2016). In the present investigation, hydroalcoholic extract of BOVLI at the dose of $400 \mathrm{mg} / \mathrm{kg}$ of dose have shown highly significant increase $(p<0.001)$ in locomotor activity. This indicates that BOVLI might have CNS stimulant activity. This result indicates that the extract might possesses CNS stimulant activity which probably act via competitive antagonism at adenosine receptors leading to increase in nor-epinephrine secretions and enhance neural activity in numerous brain areas since extract's effect was compared to caffeine (Owolabi et al., 2008). Assessment of learning, memory function and exploratory behaviors in rodents are broadly conducted by Y maze test (Aziz and Sarkar, 2016). In the present investigation, hydroalcoholic extract of BOVLI at the dose of $400 \mathrm{mg} / \mathrm{kg}$ of dose have shown highly significant increase $(p<0.001)$ in total number of entries in each arm. In negative control, rats have shown reduction in total number of entries in each arm might be due to decrease in dopamine, nor-epinephrine and serotonin level. After treatment with the extract, the total number of entries in each arm has increased. This showed that possibility of central monoaminergic system could be involved in the mode of action of extract (Thakur et al., 2014).

Depression symptoms are associated with changes in monoamine neurotransmitter (i.e., NE, DA, and 5-HT) levels in the CNS. The prefrontal cortex and hippocampus, which regulate emotion, motivation, learning, and memory, are essential in depression. NE is related to alertness, energy, and attention, and that DA is linked to pleasure, reward, and motivation in life. The 5-HT transmitter is related to compulsion, obsession, and anxiety (Du et al., 2014). In the present investigation, chronic administration of hydroalcoholic extract of BOVLI at the $400 \mathrm{mg} / \mathrm{kg}$ of dose have shown highly significant increase $(p<0.001)$ in dopamine and serotonin level. Extract of BOVLI probably act through restoration of neuro transmitters by increasing 5-HT and dopamine level at synaptic area of these monoaminergic neurons. These scientific evidences support the present investigation.

\section{Conclusion}

Hydroalcoholic extract of BOVLI florets was evaluated for CNS stimulant effect using locomotor activity and spontaneous motor activity through Y maze test apparatus. Initially were prepared. Preliminary phytochemical screening of hydroalcoholic extracts of $B$. oleracea revealed that presence of some active ingredients such as alkaloids, flavonoids, tannins, carbohydrates, glycosides, saponins, terpenoids and phenols. Acute oral toxicity study revealed the safety of the extract and further CNS stimulating activity observed by increased in locomotor and spontaneous motor activity in rats. Thereafter, the extract at higher dose shown significant increase in dopamine and serotonin level and affirmed its dose dependent potentiality as CNS stimulant.

\section{Conflict of interest}

The authors declare no conflicts of interest relevant to this article.

\section{References}

Agarwal, A.; Bora, D.; Agarwal, C. and Kumar, R. (2015). CNS stimulant and antidepressant activity of seeds of Abel moschusesculentus in rats. Bull Pharm Res., 5(2):47-50.

Alasmari, F. (2020). Caffeine induces neurobehavioral effects through modulating neurotransmitters. Saudi Pharmaceutical Journal, 28: 445-451.

Ashwlayan, V.D. (2017). Antidementic activity of Brassica oleracea L. var. italica (Brassicaceae) flower on memory deficit in young male rats. Pharm. Pharmacol. Int. J., 5(3):115-122.

Avijit, C.; Amudha, P. and Geetha, M.S.N. (2010). Evaluation of anxiolytic activity of methanolic extract of Sapindu smukorossi Gaertn. in mice. Int. J. Pharma. Bio. Sci., 1(3):1-8.

Aziz, M.A. and Sarkar, K.K. (2016). Y Maze, elevated plus maze and hole cross tests of Richardia scabra whole plant. Pharmacolgy online, 3:66-72.

Bhagat, S.V.; Varma, M.E. and Patil, R.N. (2012). Study of free readical scavenging activity and phytochemicals of the methanol extract of broccoli (Brassica oleracea). Res. J. Pharm. Biol. Chem. Sci., 3(4):623-628.

Bishwo, R.; Jyothi, Y. and Das, K. (2016). Kigelia pinnata : Exploration of potential medicinal usage in human ailments. J. Pharm. Res., 15(4): $138-146$.

Bora, D.; Sweta, K.; Jyothi, Y.; Bipul, R.; Ranjith, R. and Vinay, S. (2015). CNS stimulant activity of aqueous extract of roots of Boerhavia diffusa in mice. J. Chem. Pharm. Res., 7(10):409-412.

Das, S.; Sasmal, D. and Basu, S.P. (2008). Evaluation of CNS depressant activity of different plant parts of Nyctanthes arbortristis Linn. Indian Journal of Pharmaceutical Sciences, 70(6):803-806.

Du, B.; Tang, X.; Liu, F.; Zhang, C.; Zhao, G.; Ren, F. and Leng, X. (2014). Antidepressant-like effects of the hydroalcoholic extracts of Hemerocallis Citrina and its potential active components. BMC Complement Altern Med., 14(1):1-11.

Fekadu, N.; Shibeshi, W. and Engidawork, E. (2017). Major depressive disorder: Pathophysiology and clinical management. J. Depress Anxiety, 6(1): $1-7$.

Jäger, A.K. and Saaby, L. (2011). Flavonoids and the CNS. Molecules. 16(2): $1471-1485$.

Jayanthi, M.K.; Prathima, C.; Huralikuppi, J.C.; Suresha, R.N. and Dhar, M. (2012). Anti-depressant effects of Withania somnifera fat (Ashwagandha Ghrutha) extract in experimental mice. Int. J. Pharma. Bio. Sci., 3(1):33-42.

Kaneria, M.; Kanani, B. and Chanda, S. (2012). Assessment of effect of hydroalcoholic and decoction methods on extraction of antioxidants from selected Indian medicinal plants. Asian Pacific Journal of Tropical Biomedicine, 2(3):195-202.

Kifayatullah,M.; Mustafa, M.S.; Sengupta, P.; Sarker, M.R.; Das, A. and Das, S.K. (2015). Evaluation of the acute and sub-acute toxicity of the ethanolic extract of Pericampylus glaucus (Lam.) Merr. in BALB c mice. Journal of Acute disease, 4(4):309-315. 
Kulkarni, S. (2011). Hand book of experimental pharmacology. 9th ed Delhi: Vallabh Prakashan.

Kumari, A.; Sharma, S. and Vig, A.P. (2012). Antigenotoxic effects of Brassica oleracea L . var. italica aqueous seed extract on Allium сера root chromosomal aberration assay. Int. J. Genet., 2:22-28.

Leja, M.; Mareczek, A. and Starzynska, A.R.S. (2001). Antioxidant ability of broccoli flower buds during short-term storage. Food Chem., 72(2): 219-222.

Mestry, M.; Bajaj, A.; Rane, M. and Lalan, K. (2016). Herbal CNS stimulants Int. J. Herb. Med., 4(6):109-116.

Nargatti, P.; Patil, S.; Patil, S. and Naikwade, N. (2021). Chemopreventive potential of adrenergic blocker in behavioral stress accelerated prostate cancer development in rats, Research Journal of Pharmacy and Technology, 14(2):787-792.

Owolabi, O.J.; Amaechina, F.C. and Eledan, A.B. (2008). Central nervou system stimulant effect of the ethanolic extract of Kigelia africana. J. Med. Plants Res., 2(2):20-23.

Patil, S.; Nargatti, P.; Shikalgar, T. and Naikwade, N. (2021). Evaluation of antidepressant activity of Ficus carica leaves extract in experimental animals, Research Journal of Pharmacy and Technology, 14(3):1267-1273.

Saha, S. and Banerjee S. (2013). Central nervous system stimulant action of Alpinia galanga (L.) rhizome: A preliminary study. Indian J. Exp. Biol., 51(10):828-832.

Sarris, J.; Panossian, A.; Schweitzer, I.; Stough, C. and Scholey, A. (2011). Herbal medicine for depression, anxiety and insomnia: A review of psychopharmacology and clinical evidence. Eur. Neuropsychopharmacol., 21(12):841-860.
Shah, M.A.; Sarker, M.M.R. and Gousuddin, M. (2016). Antidiabetic potential of Brassica oleracea var. italica in type 2 diabetic sprague dawley (sd) rats. Int. J. Pharmacogn Phytochem Res., 8(3):462-469.

Sibi, G.; Shukla, A.; Dhananjaya, K.; Ravikumar, K.R. and Mallesha, H. (2013). In vitro antibacterial activities of Broccoli (Brassica oleracea $\mathrm{L}$ .var italica) against food borne bacteria. J. Appl. Pharm. Sci., 3(5):100-103.

Sonpetkar, J.M.; Patil, U.S.; Shenoy, P.A.; Tiwari,A.H.; Nipate, S.S. and Bandawane, D.D. (2012). Preclinical rvaluation of central nervous system stimulant agents: An overview. Int. J. Univers Pharm. Life Sci., 2(2):48-61.

Talreja, K. and Moon, A. (2014). Brassica oleracea: Phytochemical profiling in search for anticancer compounds. Int. J. Life Sci. Pharma. Reseach., 4(4):L1-L10.

Thakur, A.K.; Chatterjee, S.S. and Kumar, V. (2014). Antidepressant-like effects of Brassica juncea L. leaves in diabetic rodents. Reviews, 52(6):613-622.

Tripathi, K. (2013). Essentials of Medical Pharmacology. 7th ed. New Delhi: Jaypee Brothers Medical Publishers (P) LTD.

Vamsee, V.A.; Bora, D. and Upreti, S. (2015). Effect of aqueous extract of Brassica oleraceae var italica (Broccoli) inflorescence in phenylhydrazine induced anemic rats. Bull. Pharm. Res., 5(3):8183.

Zaman, A.; Khan, M.S.S.; Akter, L.; Syeed, S.H.; Akter, J.; Al Mamun, A.; Alam, M.E.; Habib, M.A. and Jalil, M.A. (2015). Exploring new pharmacology and toxicological screening and safety evaluation of one widely used formulation of Nidrakar Bati from South Asia region. BMC Complement Altern. Med., 15(1):121. doi:10.1186/s12906-0150635-2. 